\title{
Central Asia: Mackinder Revisited?
}

\author{
By Michel Hess ${ }^{*}$
}

When Alfred Thayer Mahan, an American naval officer, noted the seeming correlation between the rise of Pax Britannica in the nineteenth century and the development of the British Navy, he argued convincingly that naval capabilities were the sine qua non to national power. ${ }^{1}$ With the waning of British supremacy, however, this paradigm was challenged by technological advances in land transportation. The advent of railroads and the internal combustion engine meant that land power would assume the dominant position in the twentieth century. It was Halford Mackinder, a British geographer, who noted that, while only a quarter of the world's surface was land, the three contiguous continents of Asia, Europe, and Africa constituted two-thirds of the planet's solid surface. Mackinder referred to this landmass as the "World Island."2 The key to strategic domination, according to his model, was the "heartland," the part of Eurasia that is formed by Central Asia, the Caucasus, and parts of present-day Russia. ${ }^{3}$ Strategic domination involves exclusive access to energy resources, and Mackinder thought the World Island would contain significant portions of those resources.

While these early proponents of Geopolitik introduced important geographic considerations into strategic studies, their approach provided the foundation for policy aberrations by Nazi Germany, ${ }^{4}$ and also polarized academic debates in their time. ${ }^{5}$ It was Nicholas Spykman who introduced modifications

\footnotetext{
* Dr. Michel Hess is Chief of Section at the Service for Strategic Analysis and Prevention, Swiss Federal Department of Justice and Police, Bern. In this capacity he also serves as Switzerland's EAPC/PfP Intelligence Liaison Unit. Dr. Hess has conducted EAPC/PfP training seminars throughout Central Asia and the Caucasus.

${ }^{1}$ Alfred Thayer Mahan, The Influence of Seapower upon History, 1660-1783 (Boston: Little, Brown, 1897).

${ }^{2}$ Halford Mackinder, Democratic Ideals and Reality (New York: Holt and Company, 1919), 150:

"Who rules East Europe commands the Heartland. Who rules the Heartland commands the World Island. Who rules the World Island commands the World."

${ }^{3}$ Gerald Robbins, "The Post-Soviet Heartland: Reconsidering Mackinder," Global Affairs 8 (Fall 1993): 95-108.

${ }^{4}$ Mackinder's ideas appealed in particular to Karl Haushofer, a German geographer with considerable influence in Nazi military circles. This influence laid the foundation for many of Hitler's conceptions of Lebensraum (a term coined by Friedrich Ratzel), leading to military aggression against Eastern Europe and Russia. Haushofer and Mackinder's ideas also preoccupied American strategic research during the war, as evidenced by J. Thorndike, "Geopolitics: The Lurid Career of a Scientific System which a Briton Invented, the Germans Used, and the Americans Need to Study," Life, 21 December 1942.

${ }^{5}$ Nichols Spykman, The Geography of Peace (New York: Harcourt, Brace, 1944); Michael P. Gerace, "Between Mackinder and Spykman: Geopolitics, Containment, and After," Comparative Strategy 10 (October/December 1991): 347-64.
} 
into the school of thought by de-emphasizing the importance of the heartland, and by arguing that, "who controls the rimland rules Eurasia, who rules Eurasia controls the destinies of the world." ${ }^{\circ}$ Spykman referred to the rimland as an area roughly covering Western Europe, the Middle East, and South and East Asia. If one of the primary tasks of strategic analysis is forecasting, then Spykman's analysis has proved to be remarkably accurate. Without necessarily concluding that Spykman's work constituted "a central theoretical foundation of George F. Kennan's famous postwar proposal for a 'policy of containment' of the Soviet Union," he can be credited for predicting at least two developments after the Second World War: Russia's and China's roles in the balance of power, and U.S. protective policy towards Japan. ${ }^{7}$

What is the merit of geopolitical approaches in a post-Cold War era of rapid technological developments, digital communications, and globalized economies and polities? On their face, the distinctions between the heartland, the rimland, and the World Island have become analytically inaccurate. The empirical manifestations of this inaccuracy are manifold: globalization, intercontinental ballistic missiles, weapons of mass destruction, globally operating terrorist networks, Islamic fundamentalism, and transnational organized crime. These phenomena render any notion of territorial control functionally meaningless, regardless of military power. A more apt description of recent developments in the rimland and the heartland would outline preventive and repressive crisis management for regional stabilization and influence, or a "muddling through." But has Mackinder's heartland theory indeed become obsolete? Not necessarily. NATO's intervention in Afghanistan and the protracted engagement by coalition forces in Iraq confirm rather than undermine the value of conventional military capabilities, albeit in the form of lighter and more flexible infantry forces supported by strategic airlift. In addition, the conventional wisdom in the current foreign and security policy debate forecasts a Central Asia that will become once again entangled in a new Great Game between powers struggling to gain a foothold and resources in the heartland, much along the same lines as during the times of tsarist Russia and colonial Britain. ${ }^{8}$

This essay evaluates this renewed interest in Central Asia. It puts the region's current and projected importance in the context of the foreign policy interests of the United States, Russia, China, Turkey, and Iran, and views it in the light of regional and international security considerations. The paper advances a three-pronged argument:

\footnotetext{
${ }^{6}$ Nichols Spykman, The Geography of Peace op.cit., 43.

7 James F. Dougherty and Robert L. Pfaltzgraff, Contending Theories of International Relations (New York: Harper and Row, 1981), 65. See also G. R. Sloan, Geopolitics in United States Strategic Policy, 1890-1987 (New York: St. Martin's Press, 1988), 127-239, and Colin S. Gray, The Geopolitics of Superpower (Lexington: University of Kentucky Press, 1988).

${ }^{8}$ See for example Lutz Kleveman, The New Great Game: Blood and Oil in Central Asia (New York: Atlantic Monthly Press, 2003).
} 
- Simplifying geopolitical paradigms continue to legitimize foreign and security policy strategies by all external actors in Central Asia, with tangible implications for the tactical conduct of statecraft. Since the break-up of the Soviet Union's heartland domination, Geopolitik has even experienced - paradoxically - a veritable renaissance in both academic and policy circles. Al-Qaeda-organized and sponsored terrorist attacks have only intensified an already existing belief that the heartland bestows a geopolitical advantage to the power that controls it.

- This revival of a geopolitical approach towards Central Asia is based on inaccurate perceptions of and assumptions about the region, and exaggerated, deterministic reductions of foreign policies to competitive energy imperialism.

- Central Asia would only under a specific set of conditions become the platform for a new Great Game, but the parameters for these conditions are unlikely to emerge in the foreseeable future.

The geopolitically driven ambitions of the most important actors in the region are both ephemeral and ambiguous: ephemeral because of a lack of resources, coordination, and an honest interest in long-term sustainable development of Central Asia; ambiguous because of the difficulties encountered in the reconciliation of divergent challenges. The most prominent challenges include but are not limited to the current political order in the region, the rise of Islamism, radicalization in the absence of other alternative and viable forms of political expression, the absence of a larger vision of regionalism on the part of both Central Asian states and external powers, and the complexity of preventive and sustainable anti-terrorist measures in an environment that is marginal, fragile, and economically disadvantaged.

\section{An Uncertain Renaissance}

Central Asia has gained significant global attention for primarily two reasons: the region's role as a buffer zone and as a platform for strategic projection in the war on terror and the exploitation of energy reserves in the Caspian Sea area. The global campaign against terrorism led to an intensification of diplomatic efforts and a foreign military presence in the region comparable in intensity to the economically motivated initiatives that took place in the 1990s after the collapse of the Soviet Union. ${ }^{9}$ During the first ten years of post-Soviet independ-

\footnotetext{
${ }^{9}$ In October 2003, Russia opened the Kant air force base outside of Bishkek. 500 Russian troops will be based permanently at Kant, Russia's first new military installation on foreign soil since the breakup of the Soviet Union. The troops are part of a rapid-reaction force based on the Collective Security Treaty signed by non-GUUAM CIS member-states in Dushanbe in April 2003. Kyrgyzstan is a rare case where both American and Russian bases are located. The Manas base, however, which was set up by the United States after September 11 for airlift needs in Afghanistan, is in the process of being reduced to 1,100 men, down from 2,000, two-thirds of which are American (see The Economist, November 1, 2003, 60). The United States maintains a second, less significant base in Uzbekistan.
} 
ence, Central Asian states looked beyond Moscow primarily for capital and technology to boost their oil drilling and the exploitation of natural gas reserves. With every Al-Qaeda terrorist incident, however, it became tragically clear that the delicate balance between economic and security interests had been mismanaged by both national authorities and foreign interests. Retrospectively, the decisive factor in this miscalculation did not rest with the extraction of resources, but with their safe transportation from landlocked production sites to distant markets. ${ }^{10}$ While a pipeline that would bring fuels through Iran was impracticable, given the stalemate of U.S.-Iranian relations, Afghanistan presented itself as a convenient transit alternative. When the Taliban came to power in 1996, they found widespread financial and political support as perceived harbingers of authoritarian stability and the predictability so fundamentally important for capital investors. Al-Qaeda's militancy, with its obvious links to the Taliban regime, threw the miscalculation into sharp relief. Thus Operation Enduring Freedom, thus the seeming strategic renaissance of the rimland bordering Central Asia, fuelled by unprecedented high-level diplomatic activities and an upsurge of bilateral and multilateral assistance programs. But what kind of renaissance was it?

Without September 11 and the uninterrupted record of terrorist incidents, the structural weaknesses of state authority, the lack of legitimate (let alone democratic) institutions, protracted economic difficulties, widespread poverty, porous borders, ethnic tensions, and religious extremism would have done little to recommend Central Asia for a central role in the geostrategic spotlight. The reactive mode of the attention focused on the region underlines both the need for and the shortcomings of negatively motivated preventive security measures: stopping the operations and growth of terrorist networks; stopping the illicit narcotics trade, which targets Western markets, and narcoterrorism; ${ }^{11}$ stopping the numerous regional conflicts from developing into major ones; and preventing the interruption of unhampered access to the region's energy resources. The ostensibly renewed interest in the region by the United States, Russia, China, Turkey, and Iran finds expression in short-term tactical and improvised policies rather than any long-term strategic planning.

\footnotetext{
${ }^{10}$ Terrorist actors are acutely aware of the strategic importance of critical national infrastructures. Some of the most vulnerable elements of this infrastructure are energy transportation and transmission facilities such as power lines, pipelines, fuel tanker trucks, electric power substations, power generating plants, pipeline pumping and compressor stations, refineries, and natural gas and liquefied natural gas facilities. Typically, clandestine bombings form the core of the modus operandi against such facilities (see "Protecting Energy Facilities From Terrorist Attacks," Intersec 13:1 (January 2003): 14-17).

11 "Narcoterrorism" is not specifically recognized as a crime in most countries. Georgia, for example, is drafting legislation to do classify it as a crime. See Jemal Gakhokidze, "The Fight Against Terrorism and Crime in the Context of National, Regional and Global Security," Trends in Organized Crime 7:1 (Fall 2001): 85-91.
} 


\section{Strategic and Tactical Considerations}

While there are signs that the United States has been turning military and diplomatic resources away from Central Asia and the Caucasus towards Iraq and the Middle East in order to avoid the problems associated with strategic overextension, even a reduced U.S. presence in Central Asia will have lasting effects. Geopolitical considerations have led the United States to establish a small quasi-permanent presence in its attempt to root out the conditions that breed terrorism on the one hand, and to maintain access to Central Asia's oil and gas reserves as an alternative to Middle Eastern reserves that are subject to greater political volatility on the other. The much-reduced military presence indicates, however, that U.S. policy towards Central Asia and the Caspian region remains tactical in nature and therefore uncertain. With the successful ousting of the Taliban regime, the need for high-level engagements seems to have disappeared, even given the residual instability in Afghanistan. The U.S. military presence will therefore continue to be maintained at a modest level in Central Asia as long as Al-Qaeda operations continue, and as long as the Taliban have a small chance to return to power. With regard to energy reserves, it is clear that Russian (Siberian) and West African oil has become significantly more important for ensuring stable, diverse supplies than the Caspian basin. The completion of the Baku-Ceyhan pipeline is more likely to reduce rather than increase the American presence in the Caspian region, as already evidenced by a decline in economic assistance programs.

The rapid U.S. operational engagement in 2001 and 2002 in Central Asia, followed by a scaled disengagement in 200, is indeed symptomatic of the absence of a visionary application of any long-term strategy in the region. ${ }^{12}$ The engagement has been devoid of a broader sustainable and regional dimension beyond the ousting of Al-Qaeda leaders and the Taliban regime. The uncertain nature of the U.S. presence is an important element of the region's chronic instability. At the same time, the United States' Central Asia engagements have attracted widespread attention to the obstacles and opportunities presented by economic and cautious political reforms. Furthermore, the technical assistance programs in border management and law enforcement may in the medium term have a positive impact on regional stability, as radicalized movements encounter not only more difficult conditions for recruitment and maneuver, but also more professional and better-equipped security forces. In short, geopolitical and domestic security considerations have led the world's foremost economic, political, and military superpower to become involved in one of the most remote and powerless regions of the world. Whether this strategic choice will

\footnotetext{
${ }^{12}$ In the fiscal year 2002, the United States provided $\$ 580$ million in aid to Central Asia, as compared to $\$ 250$ million in 2001. For 2003, the level is likely to be at the 2001 level or lower. See Charles William Maynes, “America Discovers Central Asia," Foreign Affairs 82:2 (March/April 2003): $120-32$.
} 
end with an incremental decision to withdraw the remaining tactical presence remains to be seen. However, Central Asia's rapidly changing role in the global terrorism-prevention scheme is illustration enough of the legitimizing power that Mackinder's ideas still have on foreign policies which neither promote a larger vision of Central Asian regionalism nor address the complex and difficult tasks of good governance, in particular the reconciliation of democratic principles with Islamic traditions.

Unlike the United States, Russia's foreign policy is more consistently anchored in a grand strategy in the Mackinderian mode towards an area that Moscow has always considered its own backyard. With the dissolution of the convergence of interests between Russia and the United States in the immediate aftermath of September 11, this grand strategy has been further consolidated: continuing maintenance of a military presence throughout the region (in Tajikistan and Kazakhstan in particular), establishment of the new Kant military base in the Kyrgyz Republic in order to "deter terrorists and extremists of all kinds," intensified intelligence exchange and cooperation between the Federal Security Service (FSB) and Central Asian security services (FSB's annual conference of CIS intelligence chiefs), and a new military doctrine which renews Russian ambitions to regain some of the political, military, and economic influence it has ceded to the United States, China, and Turkey in the wake of September 11 . The military reassertion is directed particularly toward China, as the doctrine threatens the use of nuclear weapons against conventional attacks in "situations that are vital for the survival of Russia and its allies."

These measures indicate that Russian policy in the region is dominated by a focus on terrorism, asymmetric threats, and the desire to contain NATO's influence, pursued through the bilateral individual Partnership for Peace (PfP) programs and multilateral PfP exercises in the region, such as the Fergana Valley exercise. ${ }^{13}$ The new military doctrine places emphasis on the independent role of air power, lighter and more flexible infantry forces, special forces to counter asymmetric threats, and - most importantly - the role of military forces in defending Russian economic interests abroad and protecting Russian-speaking minorities in CIS countries. Following the classic paradigm of Geopolitik, the doctrine links domestic security to the control of the heartland through the presence of Russian troops in Central Asia. By linking fragile regimes, terrorism, and "soft" security threats to the need for control of the heartland, Moscow demonstrates that geopolitical reasoning still plays an important role in the definition of its grand strategy. Similarly, the novel system of intensified intelligence coordination strengthens Russia's information position with regard to asymmetric threats emanating from the region, notably on

\footnotetext{
${ }^{13}$ The new military doctrine was published in early October 2003 as a 73-page blueprint by the Ministry of Defense. It states notably that, "if NATO is preserved as a military alliance with its existing military doctrine, this will demand a radical overhaul of Russian military planning, including changes in Russian nuclear strategy."
} 
the penetration of Islamic fundamentalism, drug trafficking, separatist movements, and critical infrastructures. ${ }^{14} \mathrm{~A}$ joint intelligence database on organized crime and terrorism and the development of the CIS Anti-Terrorist Center in Bishkek illustrate the advantages provided by a common KGB heritage, which is still shared by many intelligence services throughout the region. Close intelligence coordination between Russia and the United States also continues to be important to the leadership in both countries, as comparative advantages in the analytical and operational intelligence fields have brought complementary advantages to both sides in Central Asia. Both sides are also benefiting from intelligence to further their economic interests, notably the promotion of leading energy corporations. As Central Asian states with hydrocarbon reserves rely on a Russian-owned pipeline system subject to trans-shipment fees, Russia considers the development of any alternative transport routes as a security threat.

China's position vis-à-vis Central Asia is characterized by a long-term consistent and geopolitically motivated foreign and security policy. Due to this consistency, China is likely to become the most important long-term power and reference point in and for Central Asia. Russian needs and interests are split between Europe and China, viewing the former as an opportunity and the latter as a competitor and threat. Potential economic cooperation between Russia and China on energy and water in Central Asia are unlikely to develop significantly as long as borders remain vulnerable and the demographic balance unfavorable. The role of the European Union in the region is most likely to be marginal, due to a significant absence of policy coordination and a lack of interest. In this vacuum, China is best positioned to seek economic integration with Central Asia. This integration will satisfy China's immense needs for energy and water, but will also create a fertile ground for Russian-Chinese conflicts over mounting Chinese influence and illegal migration. The recent long-term acquisition offensive by Chinese petrochemical corporations in Kazakhstan's giant North Caspian Sea project indicates that the world's third-largest consumer of energy is keen on boosting its already rapid economic development in the coastal areas. ${ }^{15}$ It also indicates that China has taken a head start over Russia and the United States, which are still in the early stages of negotiating oil and gas agreements in the Caspian basin.

Finally, Turkey and Iran are unlikely to become significant actors in Central Asia, although for different reasons. While Turkey acquired substantial influence and engaged in a number of business activities in Central Asia in the

\footnotetext{
${ }^{14}$ For example, the FSB and the Kazakh Committee of National Security (KNB) are thought to have exchanged data on Islamic religious groups in Central Asia. Russia's Foreign Intelligence Service (SVR) is also likely to have used the KNB's channel to Turkey.

${ }^{15}$ The long-term nature of these acquisitions is shown, for example, by China National Petroleum Corporation's pledge to invest in the development of Aktobemunaigaz over the next twenty years. China National Offshore Oil Corporation has also purchased an $8.5 \%$ stake from the British Petrol Group.
} 
1990s, the recent economic downturn has undermined Erdogan's revived panTurkic ambitions and stripped his vision of its necessary material credibility. Central Asian regimes realized that the Turkish model for a secular state with Islamic traditions cannot address national and regional challenges; nor was the divisive internal debate over European Union accession in Turkey particularly encouraging for regimes that are trying to preserve domestic stability. Iran's role as an important market for the Caucasus and Central Asia has not lived up to its potential, given Iran's geopolitically advantageous position. The reasons for this failure are manifold, but are essentially related to bureaucratic politics, political instability, imposed sanctions, and hesitant reforms. With changed domestic and external parameters, Iran is more likely to articulate geopolitical ambitions and take a proactive role in Central Asia.

\section{Structural Limitations and Caveats}

The above sketch argues that Central Asia has enjoyed a temporary revival of policy attention, but that this revival is unlikely to either yield any positive results for the region's sustainable development and democratization or a new Great Game between powers for the control of the heartland. For one, the policy attention has been primarily negatively motivated, focused on the short term, and self-interested. As part of a poor and remote region, Central Asian countries have skillfully marketed their geographic position. They have garnered shortterm benefits from the global war against terrorism, the United States' drive for a westward pipeline, Moscow's drive to keep control of Caspian oil, China's drive for an eastward route with Kazakhstan, and Iran's call for oil swaps to satisfy energy needs in the north. The long-run perspectives are already giving clear signals. First, foreign military and defense commitments are shrinking to a tactical minimum in the region. Second, the initial enthusiasm for the vastly exaggerated Caspian oil reserves has given rise to scenarios of heartland energy wars, which have proven to be completely unfounded. The magnitude of capital investments and technology required to modernize Soviet-style drilling equipment has proven prohibitive; national regulations and bureaucratic obstacles have turned investors away, for example, from oil and gas extraction in Turkmenistan; and other, more important energy reserves in Siberia and West Africa are likely to shift economic attention away from Central Asia.

Another, more positive set of preconditions would be necessary for Central Asia to maintain the long-term interest of key players and therefore to reap any sustainable benefits. These preconditions, however, do not exist at this time. First, the United States has not shown any inclination to develop a longterm strategy for the region. While geopolitical simplifications have led to increased U.S. investments in the energy sector and a diplomatic-military presence and offensive, both are likely to dwindle in the light of improved stability and more reliable alternative oil and gas reserves elsewhere. In the political 
realm, Iraq and the Middle East are more prominent stages on which the reconciliation between Islam and democratic governance has to be hammered out. Iraq is also much more likely than Central Asia to become the stage on which to develop and test the policies appropriate to the new challenges of the postSeptember 11 world. Central Asia's stability is closely tied to a functioning U.S.-Russian relationship, and only with China's assertive role will the region remain a global focus.

Second, Russia's geopolitical heartland ambitions as expressed in the new military doctrine fall short of their promise. Is Moscow willing and able to employ armed forces to further its national interests in Central Asia? Russia's willingness to pursue this course is in little doubt, as expressed by a grand strategy that draws upon Mackinderian terminology. However, given her current capabilities and sunken operational investments in Chechnya, Russia lacks both the economic and the technical means necessary for any protracted intervention in Central Asia. Capabilities for long-range and pre-emptive strikes are largely absent (outdated precision-guided weapons, aging strategic bombers, and an insufficient number of multi-purpose radars for "smart" bombs). The gap between a doctrine based on Geopolitik and the resources available to implement that doctrine lowers the probability of Russian participation in a hypothetical new Great Game.

Third, China is most preoccupied with growing political instability in Central Asia. While the United States may not have the long-term will, and Russia lacks the capabilities to follow through on its geopolitical ambitions in the heartland, China is only too concerned and aware of the importance of bordering Central Asia. Regime changes in the region will have a direct impact on Chinese national security. The continuing suppression of the Uighur population in China's Xinjang Province poses considerable challenges to a central government which attempts to eradicate or downplay the natural ethnic, linguistic, cultural, and religious affinities which the Uighurs share with the larger Central Asian zone. ${ }^{16}$ As evidenced by Chinese petrochemical takeovers, China is the key player with the most rational basis for a long-term engagement in Central Asia (escalating energy needs, population pressure, looming separatism) and adequate economic instruments and political-military clout to defend its national interests in the region.

Finally, while Turkey and Iran may have heartland-oriented grand strategies on paper, their ambitions fall even farther short than Russia's, as neither cultivates the traditional institutional linkages which provide Russia with convenient access to all Central Asian governments.

Central Asia is therefore unlikely to be turned again into a platform for a new Great Game, as the interested powers either lack the will, resources, and

\footnotetext{
${ }^{16}$ See for example Graham E. Fuller and S. Federick Starr, The Xinjang Problem (Washington,
} D.C.: Central Asia-Caucasus Institute, SAIS, 2003). 
interest, or have other priorities that absorb scarce resources. The choice of allocating economic or military assets for the implementation of tactical and strategic decisions is not an easy one. The gap between geopolitical arguments and the capabilities to follow through is particularly pronounced with respect to Central Asia. The rhetoric advanced by Turkey, the United States, and Russia reveals to a certain extent an ignorance about the region, or the persistence and fallacy of historically-rooted analogies.

What are Central Asia's realities? Why would the territorial control of Central Asia deliver any geopolitical advantages, as suggested by Mackinder's geographically deterministic model? First, even as a geographically remote region distant from open market economies, Central Asia cannot be considered a "natural fortress." The "soft" security challenges underline the vulnerability rather than the impregnability of the heartland. Thus these challenges, along with modern weapons technologies, transform heartland domination into a liability rather than an asset.

Second, while technological advances have expanded the possibilities for rapid troop movements and power projections by railroad, they also changed the strategic airlift capabilities of armed forces. Long-range bombers have weakened the fundamental importance of geography, thus calling into question the type of infrastructural base investments that were made after the Second World War. The new bases enabling U.S. strategic airlift in Romania, Bulgaria, and also Central Asia are logistically more flexible and much more modest than the first generation of bases in Western Europe.

Third, a central position in the heartland opens up considerable strategic vulnerabilities along an enormous littoral rimland, and is therefore a source of permanent insecurity. Russia's geopolitically grounded new military doctrine is therefore fully in line with its tradition to seek buffer zones against attacks through outposts. Paradoxically, any incursions into the rimland by the United States and China bolster this deeply rooted Russian insecurity even further.

Fourth, it is an illusion to expect major productivity advances in the heartland to result through external domination, as harsh climatic conditions make agriculture and mining difficult endeavors. The extraction of natural resources demands above all major capital investments, which are unlikely to create any immediate trickle-down productivity boosters at the local level. Compared to Western Europe's role in supporting the United States' rise to strategic domination, Central Asia does not seem to be able to offer the same kind of advantages.

While Eurasia's mythological role in the geographic positioning of powers seeking or maintaining global domination continues to loom large, the heartland has neither delivered any major advantages and assets to its inhabitants nor to its occupying powers. Estimates about fossil fuel reserves in the region had to be corrected massively, and the mythic quality of geopolitical argumentation has been disclosed further with the appearance of every com- 
plexity and diversity that has called the received wisdom into question. The direct application of Mackinder's heartland model to today's Central Asia is therefore unethical, immoral, and unjustifiable. Unethical because it provides a deeply flawed foreign and security policy foundation insensitive to the diversity of the region and to the security challenges, which transcend state-centric solutions. Immoral because hegemonic ambitions come at the cost of regional local development and ignore the need for effective preventive measures against asymmetric threats. Unjustifiable because heartland power does not and will never deliver the putative advantages promised by the model. The first important step towards regional stabilization and the introduction of good governance based on democratic principles, the rule of law, and human rights is therefore to acknowledge that unexamined assumptions, analogies, and outdated theories have been a driving force in policy-making towards Central Asia, and are also to a certain extent responsible for the region's weaknesses. The next step is to foster multilateral efforts that make an honest attempt at improving Central Asia's well being. These could serve as a geographic launching pad for a genuinely global preventive strategy that offers solutions for the postSeptember 11 security challenges. 


\section{Bibliography}

Dougherty, James F., and Robert L. Pfaltzgraff. Contending Theories of International Relations. New York: Harper and Row, 1981.

Gakhokidze, Jemal. "The Fight Against Terrorism and Crime in the Context of National, Regional and Global Security." Trends in Organized Crime 7, no. 1 (2001): 85-91.

Gerace, Michael P.. "Between Mackinder and Spykman: Geopolitics, Containment, and After." Comparative Strategy 10 (1991): 347-64.

Gray, Colin S.. The Geopolitics of Superpower. Lexington: University of Kentucky Press, 1988.

Kleveman, Lutz. The New Great Game: Blood and Oil in Central Asia. New York: Atlantic Monthly Press, 2003.

Mahan, Alfred Thayer. The Influence of Seapower upon History, 1660-1783 . Boston: Little, Brown, 1897.

Maynes, Charles William. "America Discovers Central Asia." Foreign Affairs 82, no. 2 (2003).

Robbins, Gerald. "The Post-Soviet Heartland: Reconsidering Mackinder." Global Affairs 8 (1993).

Spykman, Nichols. The Geography of Peace. New York: Harcourt, Brace, 1944. 